УДК 629.076:623.426

DOI https://doi.org/10.32838/2663-5941/2020.4/35

Табуненко В.О.

Харківський національний університет Повітряних сил імені Івана Кожедуба

\title{
Марценяк О.П.
}

Національна академія Національної гвардії України

Кужелович В.I.

Національна академія Національної гвардії України

\section{АНАЛІЗ ЕФЕКТИВНОСТІ ПАТРУЛЮВАННЯ В ЗОНІ РОЗВЕДЕННЯ ВІЙСЬК ІЗ ВИКОРИСТАННЯМ АВТОМОБІЛЬНОЇ ТЕХНІКИ}

Шостий рік на сході Украйни триває гібридна війна. Бойові втрати кожен день збільшуються. Розведення військ у зоні проведення бойових дій дасть змогу створити ділянки безпеки для роботи міжнародних гуманітарних організацій, а також провести розмінування територій. Для забезпечення виконання розведення військ та безпеки місиевих жителів необхідний контроль дій незаконних збройних формувань із боку Національної гвардії України та Наџіональної поліції. До сих пір немає єдиної методики оцінювання ефективності проведення патрулювання, щзо спиралася б на об'єктивні показники оиінювання: ймовірність виконання завдань із патрулювання; коефіцієнт оперативності виконання завдань, коефічієнт ресурсозабезпечення перевезень, які своєю чергою визначаються через коефічієнт оперативної готовності машин; ймовірність подолання маршруту руху машинами; ймовірність виконання завдання з патрулювання; ймовірність уникнення втрат у процесі протидї диверсійно-розвідувальним групам або порушникам від незаконних збройних формувань. Зі зміною військової обстановки з'являються нові концепиії і неординарні погляди на перегляд проведення патрулювання як у мирний час, так $і$ у воєнний період. 3 огляду на обстановку, шэо склалася при розведенні військ у зоні бойових дій на сході України, потрібні перегляд традииійного проведення й оцінювання ефективності патрулювання з використанням як різних зразків автомобільної техніки, так і пішого патрулювання, з метою недопущення неефективного витрачання економічних ресурсів. Стає очевидним, що, здійснюючи патрулювання в зоні розведення військ в умовах бойових дій, необхідно проводити планування та оцінювання варіантів технічних рішень для вибору таких із них, що можуть дати максимальний економічний ефект. У роботі запропоновано показник ефективності, який дає змогу оиінити фактичний рівень використання різних марок автомобілів в умовах патрулювання в зоні розведення військ.

Ключові слова: зона розведення військ, автомобільна техніка, показник ефективності патрулювання, ймовірність виконання патрулювання, коефічієнт ресурсозабезпечення.

Постановка проблеми. Шостий рік на сході України триває гібридна війна. Бойові втрати кожен день збільшуються. Мирні ініціативи президента України припускають розведення військ, які дадуть змогу створити окремі ділянки безпеки для роботи міжнародних гуманітарних та інших організацій, підвищити безпеку місцевого населення, а також провести розмінування територій. Українські засоби масової інформації повідомляють, що розведення військ не обмежиться Станицею Луганською, Золотим та Петрівським. На черзі до списку демілітаризованої зони можуть опинитися Широкине, Павлопіль, Піски, Опитне, Світлодарськ, Кримське та інші. Нині лінія розмежування між контрольованою та неконтрольованою територіями на Донбасі має протяжність
410 км. Розведення військ має відбуватися на відстань 1 км дзеркально від лінії розмежування, а представники незаконних збройних формувань також мають відвести свою техніку та бойовиків [1]. У Міністерстві внутрішніх справ пояснили, що навіть за умови можливого відведення Збройних сил України (далі - 3СУ) в Золотому залишаться українські поліцейські та Нацгвардія, які патрулюватимуть місцевість, як у Станиці Луганській [2]. Керівник поліції, В. Троян, заступник командувача Операції Об'єднаних Сил, заявив, що нині 3 нашої сторони діють чотири патрулі в Золотому-4 та два патрулі в Катеринівці, крім того, використовуються автопатрулі, які працюють по усьому Золотому, та ще $\epsilon$ піші патрулі спільно з Національною гвардією України [3]. 
Міністерство оборони ЗСУ пояснює, що процес розведення військ реалізується в рамках досягнутих у попередні роки домовленостей, а ЗСУ продовжують стояти на захисті суверенітету держави, дозволяючи дипломатичним шляхом відновити територіальну цілісність України. Законодавством України передбачено право військовослужбовців застосовувати вогневі засоби в разі загрози їхньому життю та здоров'ю. Розведення військ має бути не тільки дзеркальним, але й синхронним, тобто має здійснюватися обома сторонами. Основна умова початку розведення військ - дотримання режиму припинення вогню на окремій заздалегідь зумовленій ділянці місцевості протягом 7 днів. Якщо незаконні збройні формування проігнорують такі домовленості і спробують повернутися на попередні позиції, то українські військовослужбовці будуть діяти адекватно. Тому у процесі відведення військовослужбовців ЗСУ та їх техніки контролювати безпеку мирних жителів та виконання умов розведення військ будуть представники Національної гвардії України (НГУ) і співробітники Національної поліції. Таким чином, Україна не відмовляється від збройного контролю місцевості та населених пунктів. Захід будь-яких сил незаконних збройних формувань або окремих порушників буде попереджатися та присікатись. При цьому основні місця розташування 3 районів розведення військ залишаються під контролем ЗСУ.

Основу парку НГУ та національної поліції штатних засобів становить автомобільна техніка (далі - АТ), для перевезення особового складу, озброєння, боєприпасів, спеціальних засобів під час виконання службово-бойових завдань. АТ $\epsilon$ основою забезпечення не тільки рухливості підрозділів, а й одним з основних засобів проведення патрулювання під час розведення військ у зоні проведення бойових дій. Зі зміною військової обстановки з'являються нові концепції i неординарні погляди на перегляд проведення патрулювання як у мирний час [4], так і у воєнний період [5]. 3 огляду на обстановку, що склалася в процесі розведення військ у зоні бойових дій на сході України, потрібні перегляд традиційного проведення і оцінювання ефективності патрулювання як із використанням різних зразків АТ, так i пішого патрулювання, 3 метою недопущення неефективного витрачання економічних ресурсів. На забезпечення ресурсами частин і їх підрозділів дедалі більше впливає ринкова економіка, внаслідок чого виникають нові проблеми ефективного використання палива. Стає очевидним, що, здійснюючи патрулювання в зоні розведенні військ в умовах бойових дій, необхідно проводити планування та оцінювання варіантів технічних рішень і вибирати ті з них, що дають максимальний економічний ефект. Крім визначення єдиного підходу оцінювання ефективності проведення патрулювання в зоні розведенні військ в умовах бойових дій різними способами, які дадуть змогу виявити основні напрями підвищення ефективності використання АТ і сформулювати та обгрунтувати пропозиції і практичні рекомендації в рамках такого оцінювання.

Аналіз останніх досліджень і публікацій. Визначенням поняття «ефективність» займалося багато вітчизняних та закордонних вчених, серед яких можна назвати В. Андрійчука, П. Друкера, Г. Емерсона, Б. Жнякіна, Ф. Кене, А. Куценко, T. Котарбинського, С. Мочерного, I. Павленко, В. Петті, С. Покропивного, Д. Рікардо, К. Салигу, Н. Терещенко та багато інших. В роботі [6] В. Петті, Ф. Кене визначають «ефективність» як результативність управління стосовно дій такого суб'єкта управління, як уряд держави. Д. Рікардо вважає, що це економічна категорія, яка визначає співвідношення результату і визначеного виду витрат [7]; В. Андрійчук вважає, що це результативність певної дії, процесу, що вимірюється співвідношенням отриманого результату і витрат, що його спричинили [8]. С. Мочерний [9] визначає ефективність як здатність приносити ефект, результативність процесу, проєктів, які визначаються як відношення ефекту, результату до витрат. Б. Жнякін, В. Краснова [10] визначають iii як співвідношення результату (ефекту) з витратами, що викликали цей ефект. Взагалі можна зробити висновок, що більшість вчених пов'язують поняття «ефективність» із «результативністю», та нині немає єдиного підходу до визначення поняття «ефективність».

Аналіз наукової літератури свідчить, що ефективність - це найбільш загальна, визначальна властивість будь-якої цілеспрямованої діяльності, що розкривається через категорію мети й об'єктивно виражається ступенем іï досягнення 3 урахуванням витрат ресурсів і часу [11].

Основою наукових досліджень оцінювання ефективності патрулювання в зоні розведення військ із використанням АТ до виконання завдань $€$ теорія ефективності застосування військової техніки, технічна експлуатація машин, теорія надійності виробів техніки, теорія ймовірностей та математична статистика [12-14]. Основні залежності, що використовуються в процесі визначення рівня 
ефективності застосування АТ, наведені в роботах «Автотехнічне забезпечення частин та підрозділів внутрішніх військ МВС України» та «Основи технічного забезпечення. Обгрунтування рішень» $[15 ; 16]$. Пропозиції 3 оцінки показників ефективності застосування та боєготовності сучасних зразків техніки наведені в роботі «Теорія надійності та живучості елементів і систем літальних комплексів» [17]. У роботах «Автотехнічне забезпечення частин та підрозділів внутрішніх військ MBC України» та «Основи технічного забезпечення. Обгрунтування рішень» $[15 ; 16]$ розроблені аналітичні залежності коефіцієнтів боєготовності озброєння та військової техніки військових формувань від вихідних параметрів технічного забезпечення. У роботах П.П. Чабаненко, А.В. Ковтун і В.О. Табуненко $[18 ; 19]$ наведено аналіз умов використання моделей ефективності систем; в інших працях виділені особливості визначення показника ефективності військових перевезень колонами АТ [20] та шляхи підвищення ефективності використання АТ військовими підрозділами [21].

Показники ефективності мають забезпечувати: повноту інформації, що міститься в них; однозначність кількісного вираження; чутливість до експлуатаційних факторів; простоту використання і визначення 3 мінімальними витратами засобів i часу; наочність і ясний фізичний зміст $[11 ; 14]$.

Постановка завдання. Метою статті $є$ проведення аналізу коефіцієнта ефективності патрулювання в зоні розведення військ із використанням різних марок автомобільної техніки, які уможливлять висновки щодо ефективності їх використання та попереднього планування.

Виклад основного матеріалу дослідження. Для обгрунтування та проведення аналізу коефіцієнта ефективності патрулювання в зоні розведення військ із використанням різних способів дій та попереднього планування необхідно задати вихідну обстановку. Припустимо, що:

1) ділянка патрулювання зони розведення військ та забезпечення безпеки місцевих жителів становить 9 км;

2) відстань від пункту постійної дислокації сил НГУ та Національної поліції до ділянки патрулювання становить 10 км;

3) відстань від місця тимчасової дислокації підрозділів ЗСУ до зони розведення військ становить 1 км;

4) затверджена планова витрата коштів на паливо на одну добу $\mathrm{C}_{\text {заnл. }}=300$ грн;

5) ціна 1 л ДП на час розрахунків становить близько 21 грн;
6) ціна 1 л бензину А-95 становить близько 22 грн.

Для проведення патрулювання пішими патрулями НГУ та Національної поліції визначаємо доставку особового складу на ділянку патрулювання, розвезення по маршрутах, збору та доставки назад до пункту постійної дислокації, що проводиться автобусом «БОГДАН А091» (розхід пального на 100 км становить 26,5 л ДП);

Для оцінки ефективності проведення патрулювання визначимо коефіцієнт ефективності патрулювання ( $\left.\mathrm{K}_{\text {еф.патрул. }}\right)$ пішими патрулями:

$$
\mathrm{K}_{\text {еф.патрул. }}=\mathrm{P}_{\text {патр. }} \cdot \mathrm{K}_{\text {опер. }}(\mathrm{t}) \cdot \mathrm{K}_{\text {рес.заб. }} \text {, }
$$

де $\mathrm{P}_{\text {патр. }}$ - ймовірність виконання завдань із патрулювання;

$\mathrm{K}_{\text {опер. }}(\mathrm{t})$ - коефіцієнт оперативності виконання завдань із патрулювання;

$\mathrm{K}_{\text {рес.зао. }}(\mathrm{C})$ - коефіцієнт ресурсозабезпечення перевезень.

Визначимо ймовірність виконання завдань із патрулювання пішими патрулями:

$$
\mathrm{P}_{\text {патр. }}=\mathrm{K}_{\text {ОГ }} \cdot \mathrm{P}_{\text {марш. }} \cdot \mathrm{P}_{\text {вик.завд }} \cdot \mathrm{P}_{\text {nрот. }},
$$

де $\mathrm{K}_{\mathrm{OГ}}$ - коефіцієнт оперативної готовності машин;

$\mathrm{P}_{\text {марш. }}-$ ймовірність подолання маршруту руху машинами;

$\mathrm{P}_{\text {вик.завд }}-$ ймовірність виконання завдання 3 патрулювання;

$\mathrm{P}_{\text {nрот. }}$ - ймовірність уникнення втрат у процесі протидії диверсійно-розвідувальним групам (ДРГ) або порушникам від незаконних збройних формувань.

Коефіцієнт оперативної готовності для автобусів «БОГДАН А091» становить $\mathrm{K}_{\mathrm{OГ}}=1$ бо техніка нова. Коефіцієнт ймовірності подолання маршруту руху машиною при доставці особового складу патруля НГУ та національної поліції до ділянки патрулювання становить $\mathrm{P}_{\text {марш. }}=1$. Ймовірність уникнення втрат особового складу в разі

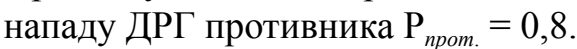

Для патрулювання пішими патрулями $\mathrm{P}_{\text {вик.завд. }}$ визначимо: кількість особового складу в підрозділах НГУ та Національної поліції, який становить 60 осіб, припустимо, що 3 них 5 осіб перебуває у відпустці, 6 осіб знаходиться в наряді на пункті постійної дислокації, 3 особи хворі та перебувають у лазареті, в строю лишаються 46 осіб. На проведення патрулювання виділяємо 12 осіб (3 піших патруля по 4 особи в кожному), ділянку в 9 км розбиваємо на 3 маршрути по 3 км, отже, патрулі перебуватимуть у зоні видимості один одного, тоді $\mathrm{P}_{\text {вик.зав. }}=1$. Таким чином: 


$$
\mathrm{P}_{\text {патр }}=1 \cdot 1 \cdot 1 \cdot 0,8=0,8 .
$$

Визначаємо коефіцієнт оперативності виконання завдань із патрулювання $\mathrm{K}_{\text {опер }}(\mathrm{t})$. Вважаємо, що особовий склад патрулів НГУ та Національної поліції вчасно прибув у зону патрулювання та під час патрулювання швидко реагує на можливі порушення, бо знаходиться на невеликій відстані один від одного та може прийти один одному на допомогу, тому $\mathrm{K}_{\text {опер }(t)}=1$.

Визначимо коефіцієнт ресурсозабезпечення перевезень $\mathrm{K}_{\text {ресззаб }}(\mathrm{C})$. Затверджена планова витрата коштів на паливо при патрулюванні становить $\mathrm{C}_{\text {запл. }}=300$ грн, витрати для доставки особового складу до місця патрулювання, розвезення усіх патрулів по запланованих маршрутах, збір та доставка усіх після патрулювання в пункт постійної дислокації становитиме 76 км автобусом «БОГДАН А091», що дорівнює $\mathrm{C}_{\text {витр. }}=422$ грн, тому:

$$
\mathrm{K}_{\text {peс.заб }}(\mathrm{C})=1-e^{-\frac{300}{122}}=0,914,
$$

тоді:

$$
\mathrm{K}_{\text {еф.патрул. }}=0,8 \cdot 1 \cdot 0,914=0,7312 \approx 0,73 .
$$

Для проведення патрулювання на бронеавтомобілі КрАЗ-Спартан (розхід пального на 100 км становить 23 л ДП) на патрулювання виділяємо один бронеавтомобіль (екіпаж 4 особи). Виходячи 3 формули (1), визначаємо коефіцієнт ефективності патрулювання на автомобілі ( $\left.\mathrm{K}_{\text {еф.патрул. }}\right)$ КрАЗ-Спартан

Далі за формулою (2) визначимо ймовірність виконання завдань із патрулювання на бронеавтомобілі КрАЗ-Спартан, де коефіцієнт оперативної готовності для бронеавтомобіля КрАЗ-Спартан ДП становить $\mathrm{K}_{\mathrm{O \Gamma}}=1$, бо техніка нова. Ймовірність подолання маршруту бронеавтомобілем при патрулюванні становить $\mathrm{P}_{\text {марш. }}=1$. Для патрулювання на бронеавтомобілі КрАЗ-Спартан визначимо: протяжність маршруту 9 км, середня швидкість руху під час патрулювання не більше 25 км/год., таким чином бронеавтомобіль проїде ділянку патрулювання за $9_{\text {ки }} / 25_{\text {ки/год }}=0,4$ год. $=24$ хвилини, за цей час може статися прорив ділянки ДРГ противника та сама ДРГ може сховатися або здійснити напад на патруль, тоді з огляду на бронезахист особового складу $\mathrm{P}_{\text {викззавд }}=0,9$.

Таким чином:

$$
\mathrm{P}_{\text {патр. }}=1 \cdot 1 \cdot 1 \cdot 0,9=0,9 .
$$

Тоді визначаємо коефіцієнт оперативності виконання завдань із патрулювання $\mathrm{K}_{\text {опер }}(\mathrm{t})$. Оскільки автомобіль може буде відсутній на певній ділянці маршруту короткий час, тому $\mathrm{K}_{\text {опер(t) }}=1$.

Припустимо, що під час патрулювання патрульний бронеавтомобіль проїде 10 разів із початку до кінця та назад по маршруту патрулювання, що становить 180 км, прибуття до місця патрулювання та повернення до пункту постійної дислокації 20 км, загалом пробіг становить 200 км.

Визначимо коефіцієнт ресурсозабезпечення $\mathrm{K}_{\text {ресззал }}(\mathrm{C})$ при затвердженій плановій витраті коштів на паливо $\mathrm{C}_{\text {запл. }}=300$ грн, а при вказаному пробігу бронеавтомобіля «КрАЗ-Спартан» витрачаємо на його заправлення $\mathrm{C}_{\text {витр }}=966$ грн, тоді:

$$
\mathrm{K}_{\text {рес.заб }}(\mathrm{C})=1-e^{-\frac{300}{666}}=0,363 .
$$

Таким чином:

$$
\mathrm{K}_{\text {еф.патрул. }}=0,9 \cdot 1 \cdot 0,363=0,3267 \approx 0,33 .
$$

Для проведення патрулювання на легковому автомобілі HYUNDAI TUCSON (розхід пального на 100 км становить 10 л бензину А-95) на патрулювання виділяємо один автомобіль (екіпаж 4-5 осіб). Виходячи з формули (1), визначаємо коефіцієнт ефективності патрулювання на автомобілі $\left(\mathrm{K}_{\text {еф.патру. }}\right)$ HYUNDAI TUCSON. Використовуючи вираз (2), визначимо ймовірність виконання завдань iз патрулювання на автомобілі HYUNDAI TUCSON, де коефіцієнт оперативної готовності для автомобіля HYUNDAI TUCSON становить $\mathrm{K}_{\mathrm{O \Gamma}}=1$, бо техніка нова. Ймовірність подолання маршруту під час патрулювання становить $\mathrm{P}_{\text {марш. }}=1$.

Для патрулювання на автомобілі HYUNDAI TUCSON визначимо: протяжність маршруту 9 км, середня швидкість руху під час патрулювання не більше 25 км/год., таким чином автомобіль проїде ділянку патрулювання за 24 хвилини, за цей час може статися прорив ділянки ДРГ противника та сама ДРГ може сховатися або здійснити напад на патруль, тоді з огляду на відсутність бронезахисту особового складу $\mathrm{P}_{\text {вик.заво }}=0,8$. Таким чином:

$$
\mathrm{P}_{\text {патр }}=1 \cdot 1 \cdot 1 \cdot 0,8=0,8 .
$$

Визначимо коефіцієнт оперативності виконання завдань із патрулювання $\mathrm{K}_{\text {опер }}(\mathrm{t})$. Враховуючи протяжність маршруту автомобіль може бути відсутній на будь-якій ділянці за короткий час, тому $\mathrm{K}_{\text {опер }(t)}=1$.

Припустимо, що під час патрулювання автомобіль проїде приблизно 200 км.

Визначимо коефіцієнт ресурсозабезпечення $\mathrm{K}_{\text {ресззаб }}(\mathrm{C})$ при затвердженій плановій витраті коштів на паливо, яка становить $\mathrm{C}_{\text {запл. }}=300$ грн, а при вказаному пробігу автомобіля HYUNDAI 
TUCSON витрачаємо на його заправлення $\mathrm{C}_{\text {витр }}=440$ грн, тоді:

$$
\mathrm{K}_{\text {рес.заб }}(\mathrm{C})=1-e^{-\frac{300}{140}}=0,883 \text {. }
$$

Таким чином:

$$
\mathrm{K}_{\text {еф.патрул. }}=0,8 \cdot 1 \cdot 0,883=0,7064 \approx 0,7 .
$$

Для проведення патрулювання на бронеавтомобілі «Варта» на базі МАЗ $4 \times 4$ (розхід пального на 100 км становить 35 л ДП) на патрулювання виділяємо один бронеавтомобіль (екіпаж $2+8$ осіб). Виходячи 3 формули (1), визначаємо коефіцієнт ефективності патрулювання на автомобілі ( $\mathrm{K}_{\text {еф.патрул. }}$ ) «Варта». Використовуючи вираз (2), визначимо ймовірність виконання завдань із патрулювання на бронеавтомобілі «Варта», де коефіцієнт оперативної готовності для бронеавтомобіля «Варта» становить $\mathrm{K}_{\mathrm{O \Gamma}}=1$, бо техніка нова. Ймовірність подолання маршруту бронеавтомобілем «Варта» при патрулюванні становить $\mathrm{P}_{\text {марш. }}=1$. Для патрулювання на бронеавтомобілі «Варта». визначимо: протяжність маршруту 9 км, середня швидкість руху під час патрулювання не більше 25 км/год., таким чином бронеавтомобіль «Варта» проїде ділянку патрулювання за 24 хвилини, за цей час може статися прорив ділянки ДРГ противника та сама ДРГ може сховатися або здійснити напад на патруль, тоді з огляду на бронезахист особового складу $\mathrm{P}_{\text {вик.завд }}=0,9$. Таким чином:

$$
\mathrm{P}_{\text {патр. }} \cdot=1 \cdot 1 \cdot 1 \cdot 0,9=0,9 .
$$

Визначимо коефіцієнт оперативності виконання завдань із патрулювання $\mathrm{K}_{\text {опер }}(\mathrm{t}) .3$ огляду на протяжність маршруту бронеавтомобіль може бути відсутній на будь-якій ділянці маршруту короткий час, тому $\mathrm{K}_{\text {опер }(t)}=1$.

Припустимо, що при патрулюванні бронеавтомобіль «Варта» проїде приблизно 200 км.

Визначимо коефіцієнт ресурсозабезпечення $\mathrm{K}_{\text {ресзаб }}(\mathrm{C})$ при затвердженій плановій витраті коштів на паливо $\mathrm{C}_{\text {запл. }}=300$ грн, а при вказаному пробігу бронеавтомобіля «Варта» витрачаємо на його заправлення $\mathrm{C}_{\text {витр }}=1470$ грн, тоді:

$$
\mathrm{K}_{\text {pec } 3 \text { аб }}(\mathrm{C})=1-e^{-\frac{300}{1170}}=0,226 .
$$

Таким чином:

$$
\mathrm{K}_{\text {еф.патрул. }}=0,9 \cdot 1 \cdot 0,226=0,2034 \approx 0,2 .
$$

Висновки. Проведений аналіз коефіцієнта ефективності патрулювання в зоні розведення військ із використанням різних марок автомобільної техніки дає змогу зробити висновки в теоретичному і практичному планах.

1. Сучасна економічна ситуація в країні висуває вимоги підвищити ефективність використання АТ. Для цього необхідно ввести єдину методику оцінки очікуваної ефективності використання АТ у процесі проведення патрулювання в зоні розведення військ в умовах бойових дій, який дасть змогу визначати вплив на неї окремих показників і намітити шляхи забезпечення їі високого рівня.

2. Запропонований показник коефіцієнт ефективності патрулювання на автомобілях дає змогу оцінити фактичний рівень використання різних марок АТ і способів патрулювання в зоні розведення військ при бойових діях.

3. При прийнятті $K_{\text {рес.заб. }}(C)=1$ проведені розрахунки уможливлюють висновки про те, що найбільша ефективність проведення патрулювання на автомобілі HYUNDAI TUCSON 3 коефіцієнтом $\mathrm{K}_{\text {еф.патрул. }}=0,7$, піші патрулі показали ефективність патрулювання 3 коефіцієнтом $\mathrm{K}_{\text {еф.патрул. }}=0,73$. Патрулювання бронеавтомобілем КрАЗ-Спартан із коефіцієнтом $\mathrm{K}_{\text {еф.патрул. }}=0,33$, бронеавтомобілем «Варта» на базі МАЗ 4x4 з коефіцієнтом $\mathrm{K}_{\text {еф.патрул. }} \oplus 0,2$ - це найнижчий показник ефективності під час патрулювання серед тих, які розглянуті. Таким чином, на ефективність патрулювання впливає багато різних факторів, тому, плануючи патрулювання в зоні розведення військ, необхідно їх враховувати.

\section{Список літератури:}

1. Ворона Ю. Уйти или остаться. Поможет ли разведения войск закончить войну на Донбассе. URL: https://www.pravda.com.ua/rus/articles/2019/10/9/7228491/.

2. Шрамович В. Коли і як відбудеться розведення військ на Донбасі. URL: https://www.bbc.com/ukrainian/features-49964246

3. Кушнір М. Куди насправді відійшли військові у Золотому і чого вони побоюються - репортаж із зони розведення. URL: https://www.radiosvoboda.org/a/text-reportazh-iz-rozvedennia-poblyzu-zolotoho/30250819. html

4. Табуненко В.О., Иванченко О.В., Буряк П.Д., Кужелович В.І. Метод визначення ефективності використання автобронетанкової техніки підрозділами НГУ при охороні громадського порядку в мирний час. Честь і закон. 2018. № 4(67). С. 83-88. 
5. Табуненко В.О., Марценяк О.П. Метод визначення ефективності використання автомобільної техніки підрозділами НГУ при патрулюванні в умовах воєнного стану. Системи озброєння і військова техніка. 2019. № 1(57). С. 136-140.

6. Огляд підходів до визначення економічної сутності поняття «ефективність» / Т.С. Морщенок, O.М. Біляк. Запоріжжя : КПУ, 2014. С. 2.

7. Організаційно-економічний механізм управління ефективністю діяльності підприємств споживчої кооперації України : монографія / А.В. Куценко. Полтава : РВВ ПУСКУ, 2008. 205 с.

8. Андрійчук В.Г. Ефективність діяльності аграрних підприємств: теорія, методика, аналіз. Київ : KHEУ, 2005. 292 c.

9. Основи підприємницької діяльності / С.В. Мочерний, О.А. Устенко, С.І. Чеботар. Київ : Академія, 2001. $280 \mathrm{c}$.

10. Економіка підприємства / Б.О. Жнякін, В.В. Краснова. Донецьк : Альфа-Прес, 2005. 159 с.

11. Надежность и эффективность в технике. Справочник в 10 т. Т. 1. Методология. Организация. Терминология. Москва : Машиностроение, 1986. 224 с.

12. Теория вероятностей и исследование операций в задачах эксплуатации и боевого применения вооружения и военной техники / М.П. Ганин, Н.Г. Кузнецова / Часть 2. Санкт-Петербург : ВМА. 1997. 467 с.

13. Теория вероятностей / Е.С. Вентцель, Л.А. Овчаров. Москва : Наука, 1973. 368 с.

14. Демидов Б.А., Хмелевская О.А. Методические основы оценивания и прогнозирования уровня качества, сравнительного анализа эффективности применения образцов вооружения и военной техники при управлении их жизненными циклами. Радіоелектронні і комп'ютерні системи. 2006. № 7 (19). С. $72-76$.

15. Автотехнічне забезпечення частин та підрозділів внутрішніх військ МВС України / К.П. Макарчук, С.А. Соколовський, Г.М. Маренко, В.І. Кужелович, С.М. Мельников, С.С. Вискребенцев, Р.І. Топчій. Харків : Академія ВВ МВС України, 2012. 235 с.

16. Основи технічного забезпечення. Обгрунтування рішень / Б.О. Дем'янчук, О.В. Малишкін. Одеса : МО України, 2014. 208 с.

17. Теорія надійності та живучості елементів і систем літальних комплексів / В.С. Харченко, А.П. Батуков, І.В. Лисенко. Харків : ХВУ, 1997. 403 с.

18. Чабаненко П.П. Закономірності та особливості оцінювання ефективності систем у бойових діях за ймовірнісними моделями. Наука і оборона. 2016. № 4. С. 16-22.

19. Ковтун А.В., Табуненко В.О. Обгрунтування показника ефективності використання автомобільного транспорту при перевезеннях / Збірник наукових пращь НАНГУ. 2018. № 1(31). С. 80-84.

20. Ковтун А.В., Табуненко В.О., Марценяк А.П. Определение показателя эффективности военных перевозок автомобильными колоннами. National security and military sciences. 2017. № 4 (vol. 3). C. 39-47.

21. Шаша І.К., Кудімов С.А. Шляхи підвищення ефективності використання автобронетанкової техніки підрозділами Національної гвардії України. Збірник наукових праць НАНГУ. 2017. № 1(29). С. 77-80.

\section{Tabunenko V.O., Martsenyak O.P., Kuzhelovich V.I. ANALYSIS OF PATROL EFFICIENCY IN THE TROUBLE BREEDING ZONE USING VEHICLES}

A hybrid war has been going on in eastern Ukraine for six years. Combat losses are increasing every day. The deployment of troops in the combat zone will create security areas for the work of international humanitarian organizations, as well as demining. To ensure the deployment of troops and the safety of local residents, it is necessary to control the actions of illegal armed groups by the National Guard of Ukraine and the National Police. There is still no single methodology for evaluating the effectiveness of patrols, based on objective evaluation indicators, such as the probability of performing patrol tasks; the efficiency of tasks; the coefficient of resource provision of transportation, which in turn is determined by the coefficient of operational readiness of machines; the probability of overcoming the route of movement of cars; the probability that the patrol task will be completed; the probability of avoiding losses in the face of sabotage and reconnaissance groups or violators from illegal armed groups. With the changing military situation, new concepts and extraordinary views on the revision of patrolling both in peacetime and in wartime are emerging. Now, given the situation with the deployment of troops in the war zone in eastern Ukraine, it is necessary to review the traditional conduct and evaluation of patrol effectiveness using different models of vehicles and foot patrols, in order to prevent inefficient use of economic resources. It is becoming clear that when conducting patrols in the area of deployment of troops in combat conditions, it is necessary to plan and evaluate options for technical solutions to select those that can give maximum economic effect. The paper proposes an indicator of efficiency, which allows to assess the actual level of use of different brands of cars in patrol conditions in the breeding area.

Key words: troop breeding zone, automobile equipment, patrol efficiency indicator, patrol probability, resource provisioning factor. 